\title{
Radiochemical Assessment of Uranium in Locally Used Marbles
}

\author{
Birendra Thapa ${ }^{1}$, Kamal Krishna Shrestha ${ }^{2 a}$, Khagendra Prasad Bohara ${ }^{2}$ \\ ${ }^{1}$ Department of Applied Sciences, Pulchowk Campus, Institute of Engineering, TU, Nepal \\ ${ }^{2}$ Central Department of Chemistry, Tribhuvan University, Kathmandu, Nepal \\ Corresponding author: ${ }^{a}$ kamalkshrestha@gmail.com
}

Received: Nov 5, 2018

Revised: Jan 1, 2019

Accepted: Jan 3, 2019

\begin{abstract}
A sensitive method is used for the extraction and determination of soluble uranium in locally used marble has been developed. Isobutyl Methyl Ketone (IBMK) was used as extractant and $0.02 \%$ (w/v) Arsenazo (III) as a chromogenic reagent. The present study assesses the gross radioactivity and extractable uranium in marble samples. A Multichannel Analyzer (MCA) coupled with $\mathrm{NaI}(\mathrm{Tl})$ crystal detector was used for the measurement of gross radioactivity whereas spectrophotometer was used to estimate the uranium contained in sample with the help of Arsenazo (III). The extraction involved the adjustment of $\mathrm{pH}$ at 0.9 . The efficient extraction was achieved by the addition of at least $10 \mathrm{~g}$ of $\mathrm{Al}\left(\mathrm{NO}_{3}\right)_{3}$. This method involved the reduction of $\mathrm{UO}_{2}{ }^{(+2)}$ to $\mathrm{U}(\mathrm{IV})$ by using granulated Zinc in concentrated hydrochloric acid. The physical measurements showed the presence of gross radioactivity in the range $266.19 \mathrm{~Bq} / \mathrm{kg}$ to $644.268 \mathrm{~Bq} / \mathrm{Kg}$ while the chemical analysis showed the uranium concentration in the range of $0.02 \mathrm{ppm}$ to 0.06 ppm.
\end{abstract}

Key Words: Arsenazo (III), IBMK, multichannel analyzer, spectrophotometer, uranium

\section{Introduction}

Radionuclides are found in air, water and soil. Every day, we inhale and ingest radionuclides present in air, food and water. Thus, radionuclides are found in human body. Natural radioactivity is common in the rocks and soil that makes up our planet, in water and oceans, and in our building materials. Marble is one of the common building materials but it contains trace amount of radionuclides. Marble are natural stones quarried from earth. It is formed from sediments under the seabed. It solidifies into stone after millions of years. Marble consists of soluble residue $(0.89 \%)$, $\mathrm{Fe}_{2} \mathrm{O}_{3}(0.28 \%), \mathrm{CaCO}_{3}(97.74 \%), \mathrm{MgCO}_{3}(1.22 \%)$, phosphoric acid (0.04\%) along with impurities: $\mathrm{SiO}_{2}, \mathrm{Fe}_{2} \mathrm{O}_{3}$, limonite, manganese, $\mathrm{Al}_{2} \mathrm{O}_{3}$ and $\mathrm{FeS}_{2}$ (pyrite) [10]. In other common building materials also consists of some natural radioactivity [4]. The radioactivity in marble is because of different concentration of ${ }^{238} \mathrm{U}(0.71-44.1 \mathrm{~Bq} / \mathrm{kg}),{ }^{232} \mathrm{Th}(0.10-32.0 \mathrm{~Bq} / \mathrm{kg}),{ }^{226} \mathrm{Ra}(0.36-32.4 \mathrm{~Bq} / \mathrm{kg})$ and ${ }^{40} \mathrm{~K}$ $(0.68-897.1 \mathrm{~Bq} / \mathrm{kg})[14]$.

Uranium is one of the major radiochemical substances in marble. Scientists have never detected harmful radiation effects from low levels of natural uranium, although some may be possible. Many 
people as well as animals have developed signs of kidney disease after intake of large amounts of uranium. There is also a chance of getting cancer from any radioactive material like uranium. Uranium can decay into other radionuclide, which can cause cancer if we are exposed to enough of them for a long enough periods. The chance of getting cancer is greater if we are exposed to enriched uranium because it is more radioactive than natural uranium. The Committee of the Biological Effects of Ionizing Radiation (BEIR) reported that eating food or drinking water having normal amount of uranium will most likely not cause cancer or other health problems in most people. The BEIR used data from animal studies to estimate that a small number of people who regularly eat food or drink water that has larger than normal quantities of uranium that could lead to bone cancer called sarcoma. The BEIR reported calculations showing that if people steadily eat food or drink water containing about $1 \mathrm{pCi}$ of uranium everyday of their lives, bone sarcomas would be expected to occur in about 1 to 2 of every million people after 70 years, based on the radiation dose alone. International organizations like the International Commission on Radiological Protection (ICRP) and the National Council on Radiation Protection and Measurements (NCRP) provide on recommendations for protecting people from materials, like uranium, that give off ionizing radiation. The federal government considers these recommendations and develops regulations and guidelines to protect public health. Environmental Protection Agency (EPA) has set a goal of no uranium in drinking water. EPA has also decided that any accidental uranium waste containing 0.1 curies of radioactivity must be cleaned up [2].

Uranium is introduced into the body mainly through ingestion of food and water and inhalation of air. The size of the uranium aerosols and the solubility of the uranium compound in the lungs and gut influence the transport of uranium inside the body. Coarse particles are caught in the upper part of the respiratory system from where they are exhaled or transferred to the throat and then swallowed. Fine particles reach the lower part of the lungs. If the uranium compounds are not easily soluble, the uranium aerosols will tend to remain in the lungs for a longer period of time, and deliver most of the radiation dose to the lungs. They will gradually dissolve and be transported into the blood stream. For more soluble compounds, uranium is absorbed more quickly from the lungs into the blood stream. About $10 \%$ of it will initially concentrate in the kidneys. Most of the uranium ingested is excreted in faeces within a few days and never reaches the blood stream. Most of the uranium in the blood stream is excreted through urine in a few days, but a small fraction remains in the kidneys, bones and other soft tissue [4]. Various procedures are available for the quantitative determination of uranium. Trace amounts of the uranium may be analyzed by neutron activation analysis [18]; Inductively coupled plasma- spectrometry [15]; Fluorometric and Colorimetric [1]; Flow injection analysis [5]; Spectrophotometric analysis [7, 11, 13, 16,17].

\section{Material and Methods}

\subsection{Preparation of Reagents}

All the reagents used were of Analytical Grade. These reagents were used without any further purification.

a) Preparation of stock uranium solution $\left(1000 \mu \mathrm{gml}^{-1}\right): 2.109 \mathrm{~g}$ of pure uranium nitrate $\left(\mathrm{UO}_{2}\right.$ $\left.\left(\mathrm{NO}_{3}\right)_{2} \cdot 6 \mathrm{H}_{2} \mathrm{O}\right)$ was weighed out accurately and dissolved in 10 percent nitric acid made in double distilled water. Final volume was made to $1000 \mathrm{ml}$ in volumetric flask and used as stock solution in which the uranium content was as follows:- $1 \mathrm{ml}$ of uranyl nitrate solution $=1000 \mu \mathrm{g}$ of uranium. 
b) Preparation of working uranium solution $\left(10 \mu \mathrm{gml}^{-1}\right)$ : $1 \mathrm{ml}$ of stock uranium solution was diluted to $100 \mathrm{ml}$ of a volumetric flask using double distilled water. $1 \mathrm{ml}$ of uranyl nitrate solution $=10 \mu \mathrm{g}$ of uranium

c) Preparation of arsenazo III solution: $0.02 \mathrm{~g}$ of Arsenazo (III) was accurately weighed and it was dissolved in double distilled water and final volume of the resulting solution was made up to mark in $100 \mathrm{ml}$ volumetric flask. Thus obtained solution contained the Arsenazo (III) as follows:

$1 \mathrm{ml}$ of Arsenazo (III) solution $=0.2 \mathrm{mg}$ of Arsenazo (III)

d) Preparation of Hydrochloric Acid (0.1M): $2.08 \mathrm{ml}$ of concentrated hydrochloric acid was diluted up to the mark in $250 \mathrm{ml}$ volumetric flask.

e) Preparation of Aluminium Nitrate: Saturated solution of $\mathrm{Al}\left(\mathrm{NO}_{3}\right)_{3} 9 \mathrm{H}_{2} \mathrm{O}$ was prepared in 100 $\mathrm{ml}$ beaker using distilled water. For the analytical works, fresh solution was prepared every day.

\subsection{Experimental Instruments}

a) Electronic Balance (GT210V) was used for weighing.

b) $\mathbf{p H}$ strips were used to measure the $\mathrm{pH}$.

c) Spectrophotometer (WPA - Linton, Cambridge Type S - 104) with $10 \mathrm{~mm}$ glass cells were used to estimate the uranium content in samples.

d) Multichannel Analyzer (MCA) coupled with $\mathrm{NaI}$ ( $\mathrm{Tl}$ ) crystal detectors were used to measure the gross radioactivity of the construction materials. This instrument is exclusively designed for gamma ray analysis with the crystal of $\mathrm{NaI}(\mathrm{Tl})$ sized $3 " \times 3 "$. The model of this instrument is named ORTEC - NORLAND'S - 5600 MCA, which has been designed to fulfill the needs for precision, reliability and versatility in radiation analysis.

\subsubsection{Collection of Samples}

Different types of marble samples were collected in plastic bags from local market.

\subsubsection{Absorption Spectra of Uranium (IV) Arsenazo (III) Complex and Adherence to Lambert-Beer Law.}

Measured volumes like $0 \mathrm{ml}, 1.25 \mathrm{ml}, 2.5 \mathrm{ml}, 3.75 \mathrm{ml}, 5 \mathrm{ml}$, and $6.25 \mathrm{ml}$ of uranium solution of concentration $10 \mathrm{ppm}$ were taken. The $10 \mathrm{ppm}$ uranium working solution was prepared by diluting $1 \mathrm{ml}$ of uranium stock solution in $100 \mathrm{ml}$ of volumetric flask. The solutions taken in different beakers were acidified with $5 \mathrm{ml}$ concentrated hydrochloric acid and $2 \mathrm{~g}$ of granulated zinc was added. The reduction process was allowed to proceed for 5 minute. This solution was then filtered through glass wool; thorough washing with 1:1 hydrochloric acid ensured complete separation. The filtrate was collected in $25 \mathrm{ml}$ volumetric flask. Then $5 \mathrm{ml}$ of 0.02 percent Arsenazo (III) was added and the volume was made up to the mark using 1:1 hydrochloric acid. The U (IV) present in solution formed a pink color complex with Arsenazo (III). The absorption spectra of pink colored U (IV) Arsenazo (III) complex was recorded in Spectrophotometer against reagent blank and $\lambda_{\max }$ was determined. At $\lambda_{\max }$ the absorption spectra of other solution was measured against reagent 
blank. The absorption spectra and Lambert - Beer plot are given in Fig. 3.1 and Fig. 3.2 [13].

\subsubsection{Preparation of Calibration Curve for the Determination of Uranium}

Measured volumes of uranium solution of $10 \mathrm{ppm}$ such as $0.5 \mathrm{ml}, 1 \mathrm{ml}, 1.5 \mathrm{ml}, 2 \mathrm{ml}$, and $3 \mathrm{ml}$ were taken and acidified with $5 \mathrm{ml}$ of concentrated hydrochloric acid and $2 \mathrm{~g}$ of granulated zinc was added. The reduction process was allowed to proceed for 5 minutes. This solution was filtered through glass wool and was washed with 1:1 hydrochloric acid. The filtrate was collected in $25 \mathrm{ml}$ of volumetric flask. Then $5 \mathrm{ml}$ of 0.02 percent Arsenazo (III) was added and made up to the mark with 1:1 hydrochloric acid. The resulting solutions were of concentration $0.2 \mathrm{ppm}, 0.4 \mathrm{ppm}, 0.6$ $\mathrm{ppm}, 0.8 \mathrm{ppm}$ and $1.0 \mathrm{ppm}$. The absorbance of pink colored complex was measured against reagent blank at $\lambda_{\max }$. Similarly, a calibration curve for various concentrations like $0.02 \mathrm{ppm}, 0.04 \mathrm{ppm}$, 0.06 ppm, 0.08 ppm, 0.10 ppm was prepared. The plots are given in Fig. 3.2.

\subsubsection{Determination of Uranium in collected sample}

$1 \mathrm{~kg}$ of each sample was taken and crushed into fine powdered form by using grinder and was sieved (particle size $125 \mu \mathrm{m}$ ). Thus formed finely powdered sample was sholved into the conical pile as a standard procedure. The top of the cone was then flattened out and divided into the quarters. Then the opposite quarters of the pile were removed. The remaining quarters were mixed to form a smaller conical pile and again quartered. This process was repeated for each sample, further crushing being carried out when necessary to till a suitable weight $(200 \mathrm{~g})$ was obtained. Then, $100 \mathrm{ml}$ of distilled water was added into the sample. Few drops of concentrated $\mathrm{HNO}_{3}$ were also added and stirred for half an hour. It was allowed for sedimentation. The solution was filtered. The sample was again washed with $100 \mathrm{ml}$ distilled water and filtered. Both the filtrates were mixed and dried to make about $5 \mathrm{ml}$. Then $10 \mathrm{~g}$ of aluminium nitrate was added and stirred to dissolve. The $\mathrm{pH}$ of this solution was adjusted around 1.0 by using powdered ammonium carbonate and $\mathrm{pH}$ meter. The solution was quantitatively transferred to $100 \mathrm{ml}$ separating funnel. Then $1 \mathrm{ml}$ of saturated aluminium nitrate solution was used for each rinsing. After extraction with $5 \mathrm{ml}$ of IBMK for 3 minutes, the aqueous phase was separated. The organic phase was treated with $5 \mathrm{ml}$ each of benzene and saturated aluminium nitrate solution. This solution was further shaken for 1 minute then the aqueous phase rejected while the organic phase was subjected for the recovery of uranium [13].

$5 \mathrm{ml}$ of $0.5 \mathrm{M}$ hydrochloric acid solution was added into organic phase and uranium was stripped from it. This action was repeated for two times and the extract was collected in a beaker. Two drops of concentrated sulphuric acid were added and evaporated till the fumes of sulphur trioxide ceased. The heating was done on the hot plate and the residue was treated with $1 \mathrm{ml}$ of water, $5 \mathrm{ml}$ of concentrated hydrochloric acid and $2 \mathrm{~g}$ of zinc granules. The reduction was allowed to continue for about 5 minutes. The solution was filtered through the glass wool and washed thoroughly with 1:1 hydrochloric acid. The filtrate was collected in a $25 \mathrm{ml}$ volumetric flask. Then $5 \mathrm{ml}$ of $0.02 \%$ of Arsenazo (III) solution was added and the volume was made up to the mark with 1:1 hydrochloric acid. The solution was homogenized and the absorbance was measured in $10 \mathrm{~mm}$ cell at $665 \mathrm{~nm}$ against a reagent blank after 20-25 minutes. The concentration of uranium was estimated with reference to calibration curve. 


\subsubsection{Gross Radioactivity Measurement by MCA}

$0.5 \mathrm{~kg}$ of the finely powdered (particle size $125 \mu \mathrm{m}$ ) marble samples was taken and gross radioactivity was measured by using Caesium as source.

\section{Results and Discussion}

\subsection{Adherence to Beer's Law and Stability}

The main source of uranium minerals in the earth crust is during the formation of earth. These uranium minerals are both physically and chemically weathered in areas with humid climates. Thus weathered samples were carried to the different area of the earth by various factors like air, water, wind and so on. The uranium has greater tendency to form soluble uranium complexes. These complexes which are formed in the environmental samples contain uranium in its hexavalent state [3]. The efficiency of extraction of uranium was enhanced by reducing the hexavalent state of uranium into tetravalent uranium by using zinc metal in hydrochloric acid. Since the uranium (IV) reacted with Arsenazo (III), to give pink colored U (IV) Arsenazo (III) complex whose showed its maximum absorbance at wave length $665 \mathrm{~nm}$. This value is found to match with the absorption spectra of U (IV) Arsenazo (III) complex reported [8]. The spectrum obtained here is shown in Fig. 3.1 below. The complex was not stable for a long period of time. It was found that the maximum absorbance was between 20-25 minutes and decreased gradually.

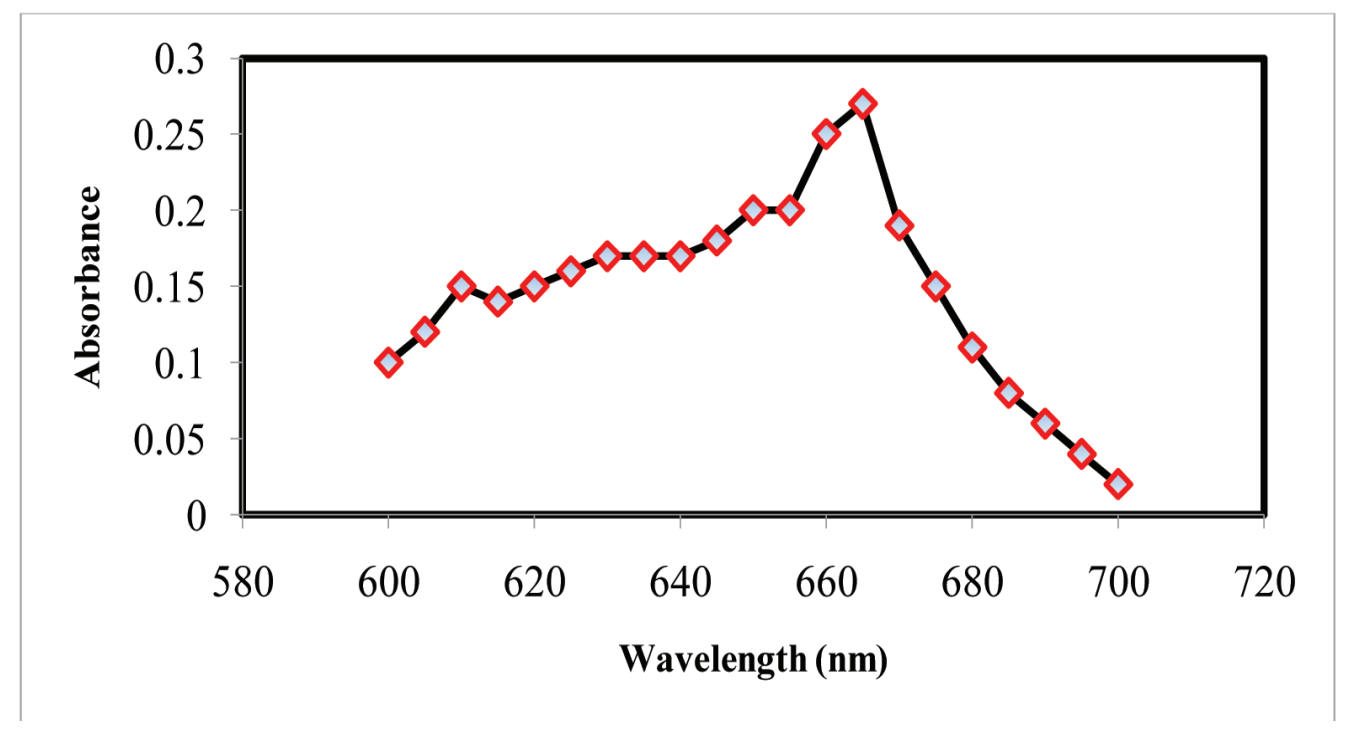

Fig. 3.1: Absorption spectra of Pink Colored Arsenazo (III) Complex

\subsection{Calibration Curve for the Determination of Uranium}

The Concentration of uranium in marble was determined using the calibration curve. Here, uranium (IV) Arsenazo (III) complex was prepared. The maximum absorbance of the colored solution was found to be $665 \mathrm{~nm}$. The concentration is expressed in ppm. 


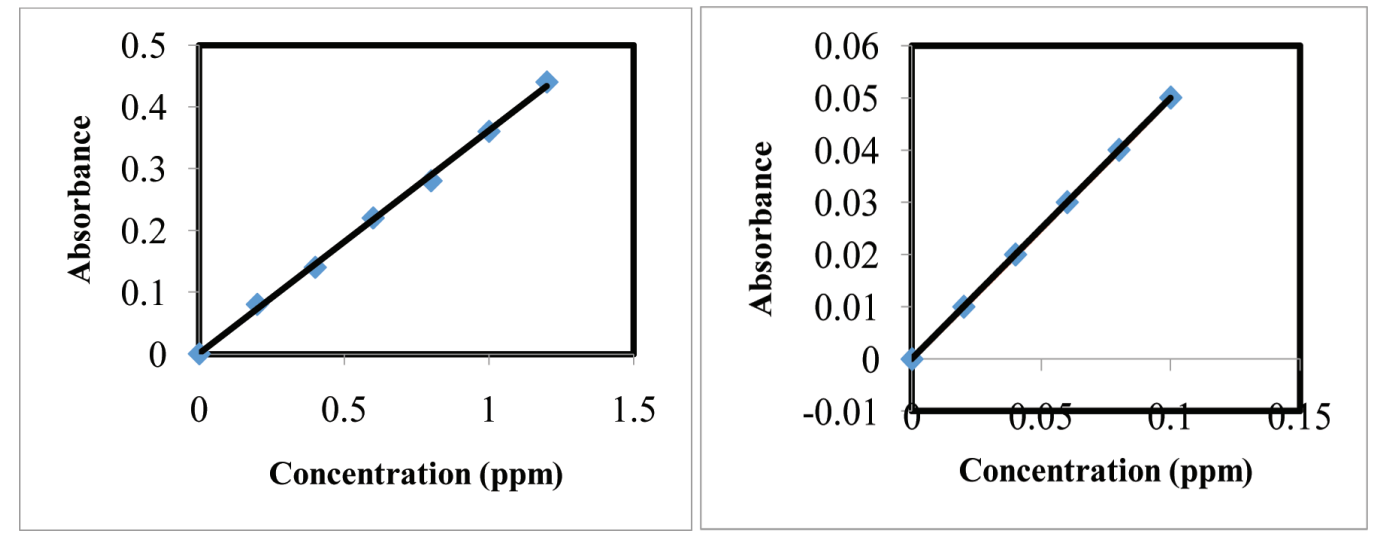

Fig. 3.2: Calibration Curves for the Determination of Uranium

\subsection{Effect of Amount of Aluminium Nitrate on Extraction}

Uranium was extracted quantitatively in acidic medium using $6 \mathrm{M}$ to $16 \mathrm{M}$ nitric acid. Aluminium nitrate was used for extraction of uranium. The main role of aluminium nitrate was to make the solution more acidic. The efficiency of extraction was investigated by varying the amount of aluminium nitrate from 2 to 14 grams at $\mathrm{pH} 0.9$ to 1 . A plot of percentage extraction versus concentration of aluminium nitrate is shown in Fig. 3.3. This curve showed the uranium was quantitatively extracted into IBMK when amount of aluminium nitrate was 10 grams. If the concentration of aluminium nitrate was lowered, the extraction becomes less. At low concentration of aluminium nitrate, the solution was not acidic. The extraction of uranium remained unchanged on increasing aluminium nitrate and faced difficulty to dissolve more amount of aluminium nitrate in $5 \mathrm{ml}$ of sample solution [13].



Fig. 3.3: Effect of Aluminium Nitrate on Extraction of Uranium 


\subsection{Effect of pH on Extraction}

On dissolving $10 \mathrm{~g}$ of aluminium nitrate in $5 \mathrm{ml}$ test solution, the $\mathrm{pH}$ decreased to 0.5 . This $\mathrm{pH}$ value was adjusted to the order of 0.8 to 0.9 by using ammonium carbonate. The reduced $\mathrm{pH}$ was due to hydrolysis of aluminium nitrate. The variation of acidity was brought about by using ammonium carbonate. A plot of extraction percentage versus acidity $(\mathrm{pH})$ values is shown in Fig. 3.4. This figure showed that extraction was quantitative at low $\mathrm{pH}$ values. On increasing the $\mathrm{pH}$ values, the percentage of extraction becomes less. At $\mathrm{pH} 2.5$ and 3.0, only 15 percent and 5 percent uranium was extracted respectively. At $\mathrm{pH}$ range of 0.5 to 1.5 , the results showed quantitative extraction of uranium upto 98 percent.

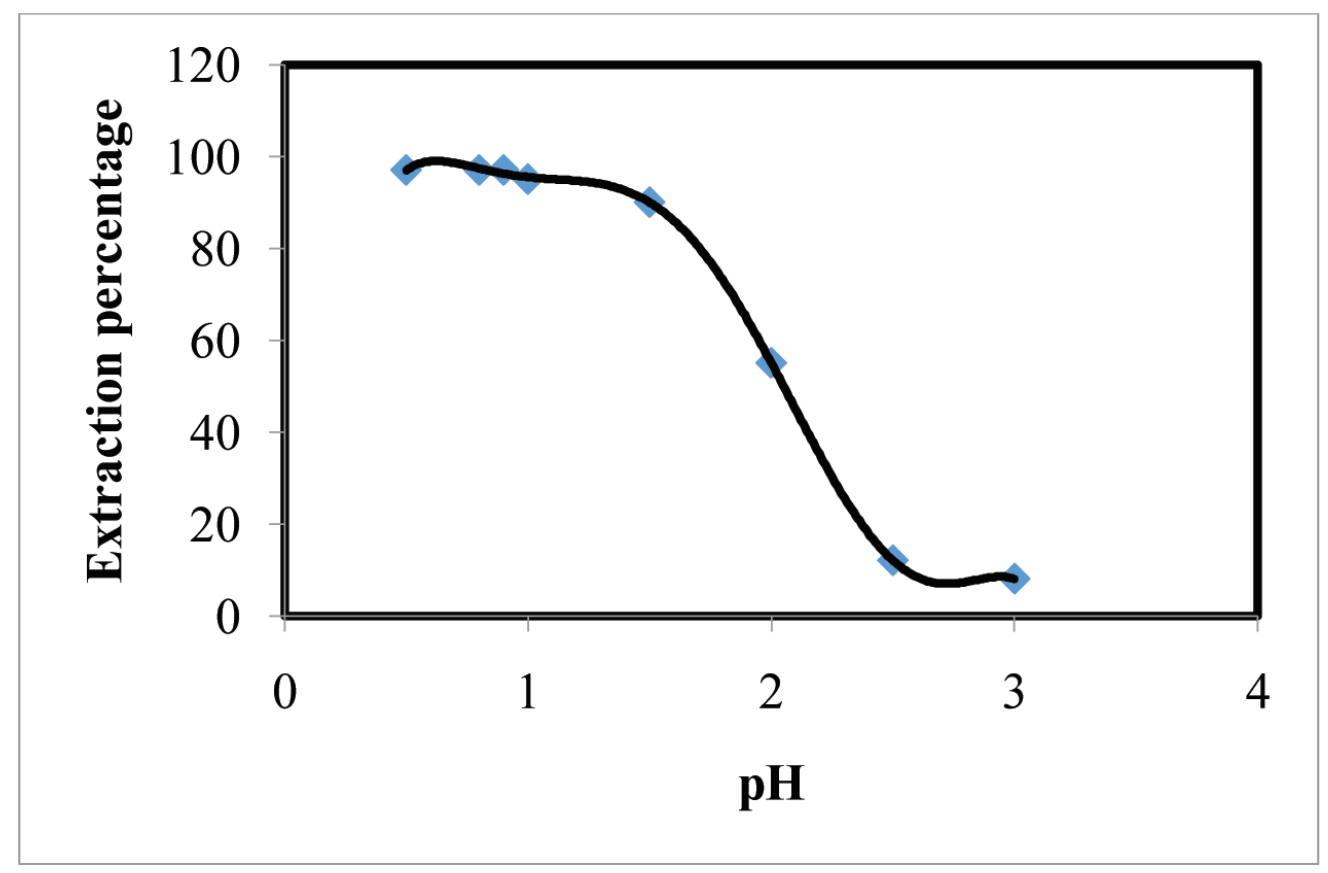

Fig. 3.4: Effect of pH on extraction of uranium

\subsection{Extraction of Uranium}

The environmental uranium has greater tendency to form soluble complexes. These complexes which are found in the environmental samples contain uranium in its hexavalent state [3]. The efficiency of extraction of uranium was enhanced by reducing the hexavalent state of uranium by using zinc metal in hydrochloric acid. One of the important factors affecting extraction of uranium is the $\mathrm{pH}$. Here the $\mathrm{pH}$ was maintained around 1 . This $\mathrm{pH}$ value was chosen because the extraction was significant at this condition. Extraction was conveniently brought about by dissolving $10 \mathrm{~g}$ of aluminium nitrate $\mathrm{Al}\left(\mathrm{NO}_{3}\right)_{3}$ in $5 \mathrm{ml}$ of the sample solution. The solubility of uranium salts in certain organic solvents was used to separate uranium from other metal ion by the solvent extraction process by the use of IBMK, diethyl ether and tributyl phosphate (TBP). These are natural extractants [12]. The extraction is based on the formation of natural non-ionized complex according to the following reaction:

$$
\mathrm{UO}_{2}^{+2}(a q)+2 \mathrm{NO}_{3}^{-}(\mathrm{aq})+2 \mathrm{TBP}(\text { org }) \rightarrow \mathrm{UO}_{2}\left(\mathrm{NO}_{3}\right)_{2} .2 \mathrm{TBP}(\text { org })
$$


In fact the sample solution might contain thorium along with uranium. In this condition aluminium nitrate $\mathrm{Al}\left(\mathrm{NO}_{3}\right)_{3}$ at $\mathrm{pH} 1$ was ineffective to extract uranium completely into aqueous phase. In order to bring the uranium selectively to the aqueous phase, benzene was used. Replacing the aqueous phase by $5 \mathrm{ml}$ saturated aluminium nitrate $\mathrm{Al}\left(\mathrm{NO}_{3}\right)_{3}$ solutions and equilibrating for one minute with IBMK extract after the addition of $5 \mathrm{ml}$ benzene increases the recovery of the uranium. A shaking time of 1 minute was found to be more efficient for quantitative extraction of uranium into IBMK. After equilibration in about 3 minutes with saturated aluminium nitrate and benzene did not affect the recovery of uranium and uranium was found in organic phase. The uranium present in the organic phase is stripped by using $0.1 \mathrm{moll}^{-1}$ hydrochloric acid. Thus obtained resulting solution was evaporated on the hot plate along with the few drops of concentrated sulphuric acid. The concentrated sulphuric acid helps in oxidizing the organic substances. The residue having uranium was then treated with $1 \mathrm{ml}$ of water, $5 \mathrm{ml}$ of concentrated hydrochloric acid and 2 grams of Zinc acts as good reducing agent. By reducing U (VI) to U (IV), the determination of concentration of uranium in various samples greatly increased.

\subsection{Sample Analysis}

The spectrophotometric analysis for determination of uranium in the solution depends on the absorbance peak of uranium (IV) at $665 \mathrm{~nm}$. First of all, $1 \mathrm{~kg}$ of each sample was taken and crushed into fine powdered form and sieved (particle size $125 \mu \mathrm{m}$ ). Thus formed finely powdered sample was taken and by standard procedure, as described earlier, a suitable weight (200 g) was obtained. Then, $100 \mathrm{ml}$ of distilled water was added into the sample. Few drops of concentrated $\mathrm{HNO}_{3}$ were also added and stirred for half an hour. It was allowed for sedimentation. The solution was filtered. The sample was again washed with $100 \mathrm{ml}$ distilled water and filtered. Both the filtrates were mixed and dried to make about $5 \mathrm{ml}$. Then $10 \mathrm{~g}$ of aluminium nitrate was added and stirred to dissolve. The $\mathrm{pH}$ of this solution was adjusted around 1.0 by using powdered ammonium carbonate and $\mathrm{pH}$ meter. The solution was quantitatively transferred to $100 \mathrm{ml}$ separating funnel. Then $1 \mathrm{ml}$ of saturated aluminium nitrate solution was used for each rinsing. The organic extractant named IBMK was used for extraction of uranium because of its low co-extraction percentage as well it did not bring down thorium and other metals to the aqueous phase completely. Benzene was chosen in order to return co-extracted metals to the aqueous phase. Equilibrium of phase after the addition of $5 \mathrm{ml}$ of benzene, however, caused the decrease in the recovery of uranium. This was overcome by $5 \mathrm{ml}$ of saturated aluminium nitrate solution. A shaking time of 1 minute was found to be sufficient for quantitative extraction of uranium in to IBMK. The uranium of organic phase was stripped using $0.1 \mathrm{M}$ hydrochloric acid. The resulting solution was evaporated after adding two drops of concentrated sulphuric acid which helps in oxidation of the organic substances. The residue containing uranium was treated with $1 \mathrm{ml}$ water and $5 \mathrm{ml}$ concentrated hydrochloric acid acts as the best reducing agent. This reducing agent reduced the $\mathrm{UO}_{2}^{+2}$ to $\mathrm{U}$ (IV) as shown below:

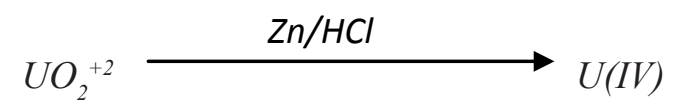

By using the Arsenazo (III) solution, U (IV) Arsenazo (III) complex was prepared and absorbance was measured at $\lambda_{\max }$ i.e., $665 \mathrm{~nm}$. The concentration of uranium in different granite and marble was determined using calibration curve. 
Table 3.1: Gross Radioactivity $(\mathrm{Bq} / \mathrm{kg}$ ) and Uranium concentration in different Marble Samples

\begin{tabular}{|l|l|l|l|l|}
\hline S.N. & Samples & Origin & Gross radioactivity(Bq/kg) & $\begin{array}{l}\text { Concentration of } \\
\text { Uranium (ppm) }\end{array}$ \\
\hline 1. & Red Alikanta & Italy & 613.31 & 0.04 \\
\hline 2. & Silvia & Egypt & 266.19 & 0.02 \\
\hline 3. & Morwad White & India & 557.15 & 0.04 \\
\hline 4. & Emperador Dark & Turkey & 644.268 & 0.06 \\
\hline 5. & Deemartino & India & 596.23 & 0.04 \\
\hline
\end{tabular}

Gross radioactivity of various marble samples was calculated (with $1 \mathrm{~kg}$ of sample) with the help of Multi - Channel Analyzer (MCA) coupled with NaI (Tl) crystal detectors. The gross radioactivity of radionuclides among the samples varied from a minimum of $266.19 \mathrm{~Bq} / \mathrm{kg}$ to the maximum of $644.268 \mathrm{~Bq} / \mathrm{kg}$. Also the chemical analysis showed that the concentration of uranium in the marble samples ranged from $0.02 \mathrm{ppm}$ to $0.06 \mathrm{ppm}$.

It can be seen from the results that uranium concentration and gross radioactivity varied appreciably from sample to sample. It may be due to variation in the location of the raw materials from where they are derived and the percentage of constituents used by manufacturers as these parameters depends upon the distributions of naturally occurring radionuclides present in the earth crust since these radionuclides are not uniformly distributed. These results are in tune with Saleh et al. [14]. All rocks have a small amount of radioactivity in them due to the presence of minerals that contain radioactive elements uranium (U), thorium (Th) and potassium-40 (K40). Most of the minerals in marble contain some radio elements; the white or pink feldspars contain K40, the black biotites and horn-blendes contain $\mathrm{K} 40, \mathrm{U}$ and $\mathrm{Th}$, and the small inclusions of minerals such as zircon, apatite, sphene, etc. contain the most $\mathrm{U}$ and $\mathrm{Th}[10,9]$.

\section{Conclusion}

The physical method includes gross radioactivity in marble samples by using the MCA. The gross radioactivity was found to be in the range $266.19 \mathrm{~Bq} / \mathrm{kg}-644.268 \mathrm{~Bq} / \mathrm{kg}$ with maximum gross radioactivity for the "Emperador Dark". The spectrophotometric determination of uranium in different marble samples was carried out by forming a complex of Arsenazo (III) with uranium in highly acidic medium. The soluble uranium complexes are found in the environmental samples with having uranium in its hexavalent state. The efficiency of the extraction was enhanced by reducing the hexavalent state of uranium into tetravalent uranium by using zinc metal in hydrochloric acid. For the extraction the use of aluminium carbonate to adjust the $\mathrm{pH}$ was found to be beneficial. IBMK used as organic solvent and benzene used to increase the efficiency of extraction were helpful. The determination of uranium by this method was extremely sensitive, rapid and cheaper and can be used in the assay of ppm level of uranium. The concentration of uranium was found in the range of $0.02 \mathrm{ppm}$ to $0.06 \mathrm{ppm}$. From the table, the "Silvia" marble had the maximum uranium concentration which was found to be $0.06 \mathrm{ppm}$. Measurements presented in this work confirm that radiation exposure and attributed risk should be reduced by careful choice of marble during construction. 


\section{References}

[1] Adams JAS and Maeck WJ (1954), Flurometric and Colrimetric Microdetermination of Uranium in Rocks and Minerals, Analytical Chemistry, 26: 1635-1640.

[2] ATSDR (1999), Toxicological profile for uranium, US Department of Health and Human Services, Public Health Service, Agency for Toxic Substances \& Disease Registry, Atlanta, GA.

[3] Fairbridge RW (Chief in Editor) (1972), Encyclopedia of Earth Sciences Series IV (A), Vannostrand Reinhold Company, New York: 1215-1224.

[4] Harley JH, Holtzman RB, Lowder WM, Meyerhof DP, Tanner AB and Wogman NA (1987), Exposure of the population in the United States and Canada from Natural Background Radiation, NCRP, Report No. 94, National Council on Radiation Protection and Measurements.

[5] Hirano Y, Ogawa Y and Oguma K (2003), Simultaneous Spectrophotometric determination of uranium and thorium by Flow Injection Analysis Using Selective masking, The Japan Society for Analytical Chemistry, 19: 303-307.

[6] IAEA (2008), Fuel-management/depleted-uranium, International Atomic Energy Agency, (Accessed on 18 October, 2008, https://www.iaea.org).

[7] Khan MH, Warwick P and Evans N (2006), Spectrophotometric determination of uranium with Arsenazo-III in perchloric acid, Chemosphere 63(7): 1165-1169.

[8] Lee JD (1996), Concise Inorganic Chemistry, $5^{\text {th }}$ edition, ELBS, Croatia, 890-895.

[9] Natural Stone Countertops and Radon (2009), Environmental Health and EngineeringAssessing Exposure to Radon and Radiation from Granite Countertops.

[10] Nelson LN (2009), Environmental Engineering: Environmental Health and Safety for Municipal Infrastructure, Land Use and Planning, and Industry, John Wiley \& Sons, ISBN 978 - 0 - 470 $08305-5$.

[11] Nietzel OA and Sesa MA(1957), Spectrophotometric Determination of Uranium with Thiocyanate in Butyl Cellosolve-Methyl Isobutyl Ketone - Water medium, Analytical Chemistry, 29: 756759.

[12] Parker S (1983), Encyclopedia of Chemistry, (ed.) Mc Graw Hill Book Company, New York, 1097-1102.

[13] Ramakrishna TV and Murthy RSS (1980), Determination of Uranium and Thorium with Arsenazo (III) after Sequential Extraction from Acid-Deficient Aluminium Nitrate Medium, Bulletin of Chemical Society, Jan., 53 (8): 2376-2379.

[14] Saleh FS and Berzan B (2007), Measurement of natural radioactivity in some kinds of marble and granite in Riyadh region, J. of Nuclear and Radiation Physics, 2(1): 25-36.

[15] Sasmaz A and Yaman M (12 ${ }^{\text {th }}$ Oct, 2008), Determination of Uranium and Thorium in soil and plants parts Abandoned Lead-Zinc-Copper Mining Area, Communications in soil Science and Plant Analysis, 39: 2568-2583.

[16] Taketatsu T (1984), Spectrophotometric Study of Uranium (VI) Chelate Formation with $\beta$-Diketones and Tributyl Phosphate in Aqueous, Nona (Oxyethylene) Dodecyl Ether Solution, Talanta, 31 (10A): 805-808.

[17] Teixeira LSG, Costa ACS, Ferreira SLC, Freitas ML and Carvalho MS (1999), Spectrophotometric Determination of Uranium using 2-(2-Thiazolylazo)-p-Cresol in the Presence of Surfactants, $J$. Braz. Chem.Soc., 10(6): 519-522.

[18] Yaprak G, Cam NF and Yemer G (1998), Determination of Uranium in plants from high background area by instrumenta neutron activation analysis, J. Radioanalytical and Nuclear Chemistry, 238 (1-2): 167-173. 